\title{
Solvent Extraction of Neem Oil from Neem Seed for Development of Ecofriendly Pesticides
}

\author{
Rita Awasthi, Deepti Shikha \\ Department of Chemistry, Brahmanand P.G. College, Kanpur, Uttar Pradesh, India
}

\begin{abstract}
How to cite this paper: Rita Awasthi | Deepti Shikha "Solvent Extraction of Neem Oil from Neem Seed for Development of Ecofriendly Pesticides" Published in International Journal of Trend in Scientific Research and Development (ijtsrd), ISSN: 24566470, Volume-3 | Issue-3, April 2019, pp.119-122, URL: http://www.ijtsrd.co $\mathrm{m} /$ papers/ijtsrd216 84.pdf

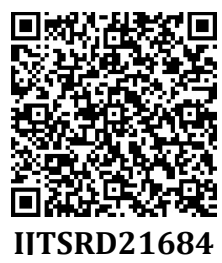

Copyright (c) 2019 by author(s) and International Journal of Trend in Scientific Research and Development Journal. This is an Open Access article distributed under the terms of the Creative Commons

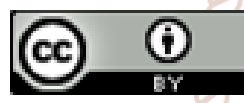
Attribution License (CC BY 4.0) (http://creativecommons.org/licenses/ by/4.0)

\section{INTRODUCTION}

Neem (Azadirachta indica) is regarded as "The Wonder Tree" and "Nature's Drug Store", because its extracts have a vast pharmacological activity and are used as raw materials for pesticide, medicine and other commodities. All parts of neem such as leaves, bark, flower, fruits, seeds and roots have advantages in medical treatment and industrial products. Neem seed is a part of neem tree which has high concentration of oil which is widely used as insecticides, lubricant, drugs for diseases like diabetes and tuberculosis [1-2]. There are several methods to obtain neem oil from the seeds like mechanical pressing, supercritical fluid extraction and solvent extraction. The most widely used method to extract neem oil from neem seed is mechanical extraction but the oil produced by this method has low price since it is turbid and contains significant amount of water and metal content. Extraction by supercritical fluid produces oil with high purity but the operating and investment cost is high.As compared to the above two methods extraction using solvent has many advantages like it gives higher yield and less turbid oil and also has low operating cost.

Several attempts have been made in the past by different scientists for upgrading the quality of neem oil and detoxification of neem meal[3-9]. However, a systematic study with greater emphasis on economy of process and better utilization of deoiled meal is still lacking. Therefore, a systematic and detailed study on the processing of neem seed was carried out to obtain the oil and deoiled meal free from non-lipid associates commonly termed as bitters. Neem oil is $100 \%$ natural and non-toxic to humans and pets, is inexpensive, and offers a long-term solution to pest problems. Since the oil is completely environmentallyfriendly and easily broken down, more and more people are turning to neem oil as a biopesticide for their home and garden.

\section{MATERIAL AND METHODS:}

The neem seeds used in this study were obtained from the local market. Prior to use, the neem seeds were repeatedly washed to remove the dirt and other impurities and subsequently dried in oven at $50^{\circ} \mathrm{C}$ until it reached constant moisture content.The experimental sample of neem seed obtained was analysed for the physio-chemical characteristics of seed, its extracted oil and deoiled meal employing standard AOCS [10] procedures. The fatty acid composition of the oil was determined by gas liquid chromatography. Results are given in Table 1.

The studies on the processing of neem seed kernels i.e. oil extraction was carried out in two steps. The first step 
constituted the single-stage pre-treatment of the neem seed kernels employing different solvents, viz., isopropanol, acetone and ethanol, in pure and aqueous forms followed by the second step, which constituted the subsequent extraction of oil with n-hexane. The pre-treatment of crushed (10-30 mesh) neem seed kernels was carried out in laboratory scale batch extractor by filling the material in a thimble placed in the extractor with solvent keeping the seed to solvent ratio of $1: 3 \mathrm{w} / \mathrm{v}$ circulating hot water in extractor jacket to maintain the temperature and keeping the material immersed in the solvent for $8 \mathrm{hr}$.

After the completion of the extraction period, the solvent extract was drained and solvent was distilled off. The nonlipid associates obtained were separated from oil by extraction with petroleum ether followed by distillation of ether to recover the oil which was analysed for its non-lipid associates content. In the second step, the pre-treated oilseed kernels obtained after the first step were subsequently extracted with n-hexane to recover the residual oil. The oil and meal thus obtained were analysed for their content of non-lipid associates and other characteristics.

The pre-treatment of neem seed kernels by the above process was carried out, first with aqueous ethanol (water: ethanol 15:85, v/v) at different temperatures varying between $50-60^{\circ} \mathrm{C}$ for $8 \mathrm{hr}$. The temperature of $55^{\circ} \mathrm{C}$ was found to be the optimum (Table 2). Further studies with ethanol, acetone and isopropanol were carried out at the pre-treatment temperature of $55^{\circ} \mathrm{C}$ and for a period of $8 \mathrm{hr}$. in the similar way. The oils recovered from the solvent extracts and the deoiled meal were analysed as given before. In the single stage process, aqueous ethanol (water: ethanol, $15: 85 \mathrm{v} / \mathrm{v}$ ) was considered to be optimum as it gave the best results (Table 3 ).

Table 1: Characteristics of neem seed, crude oil and deoiled meal

\begin{tabular}{|c|c|}
\hline $\begin{array}{l}\text { Neem Seed, \% } \\
\text { Kernel } \\
\text { Moisture } \\
\text { Oil Content } \\
\text { Total bitters contenta } \\
\text { Physio-chemical characteristics of crude neem oil } \\
\text { Sprcific Gravity, } 30^{\circ} \mathrm{C} \\
\text { Refracive Index, } 40^{\circ} \mathrm{C} \\
\text { Lovibond Colour (1cm cell) } \\
\text { Free fatty acid content } \\
\text { Iodine value } \\
\text { Saponification value } \\
\text { Bitters content, \% } \\
\text { Fatty acid Composition, \% Research and } \\
\text { Palmitic } \\
\text { Stearic } \\
\text { Oleic } \\
\text { Linoleic } \\
\text { Deoiled neem meal, \% } \\
\text { Protein } \\
\text { Crude fibres } \\
\text { Moisture } \\
\text { Bitters }\end{array}$ & $\begin{array}{l}0.9083 \\
1.4622 \\
30.0 \mathrm{Y}+4.6 \mathrm{R}+1.0 \mathrm{~B} \\
15.4 \\
69.0 \\
194.2 \\
8.1(3.5)^{\mathrm{b}} \\
17.9 \\
19.4 \\
49.9\end{array}$ \\
\hline
\end{tabular}

Table 2(a): Effect of single stage pre-treatment of neem seeds with aq. ethanol on bitters content and other characteristics of neem oil.

\begin{tabular}{|c|c|c|c|c|}
\hline \multicolumn{5}{|c|}{ Bitters Content* } \\
\hline $\begin{array}{c}\text { Temperature of } \\
\text { extraction }{ }^{\circ} \mathrm{C}\end{array}$ & $\begin{array}{c}\text { Aq. Ethanol } \\
\text { extract \% }\end{array}$ & $\begin{array}{c}\text { Oil obtained from aq. } \\
\text { Solvent extract\% }\end{array}$ & $\begin{array}{c}\text { Oil obtd by hexane extract of } \\
\text { pretreated kernel \% }\end{array}$ & $\begin{array}{c}\text { Deoiled } \\
\text { meal \% }\end{array}$ \\
\hline 50 & 3.4 & 0.8 & 0.67 & 0.61 \\
55 & 3.6 & 0.7 & 0.62 & 0.61 \\
60 & 3.5 & 0.7 & 0.71 & 0.61 \\
\hline
\end{tabular}

Table 2(b): Effect of single stage pre-treatment of neem seeds on the characteristics of neem oil

\begin{tabular}{|c|c|c|c|c|c|c|c|c|c|}
\hline \multicolumn{10}{|c|}{ Characteristics of oil } \\
\hline \multicolumn{5}{|c|}{ Oil obtained from aq.ethanol extract } & \multicolumn{5}{|c|}{$\begin{array}{c}\text { Oil obtained by hexane extraction of pre-treated } \\
\text { neem kernels }\end{array}$} \\
\hline \multirow{2}{*}{ Recovery ${ }^{*} \%$} & \multirow{2}{*}{ FFA $\%$} & \multicolumn{3}{|c|}{$\begin{array}{l}\text { Lovibond colour } \\
\text { (1 } \mathrm{cm} \text { cell) }\end{array}$} & \multirow{2}{*}{ Recovery $\%$} & \multirow{2}{*}{ FFA $\%$} & \multicolumn{3}{|c|}{$\begin{array}{l}\text { Lovibond colour } \\
\text { (in } 1 \mathrm{~cm} \text { cell) }\end{array}$} \\
\hline & & $\mathbf{Y}$ & $\mathbf{R}$ & B & & & $\mathbf{Y}$ & $\mathbf{R}$ & B \\
\hline 8.2 & 44 & 30 & 7.4 & 2.0 & 34.1 & 7.1 & 30 & 3 & 0.3 \\
\hline 7.6 & 43 & 30 & 7.0 & 2.0 & 35.6 & 7.0 & 24 & 2 & 0.0 \\
\hline 7.6 & 42 & 30 & 7.6 & 2.4 & 35.5 & 7.9 & 30 & 3 & 0.4 \\
\hline
\end{tabular}


Table3: Effect of single-stage pre-treatment of neem seeds on bitter content of neem oil and deoiled meal employing different aqueous solvents.

\begin{tabular}{|c|c|c|c|c|c|}
\hline \multirow[b]{2}{*}{ Solvents } & \multicolumn{5}{|c|}{ Bitters content*, \% } \\
\hline & $\begin{array}{l}\text { Solvent: } \\
\text { Water } \\
\text { ratio }\end{array}$ & $\begin{array}{l}\text { Aqueous } \\
\text { Solvent } \\
\text { extrace }\end{array}$ & $\begin{array}{l}\text { Oil recovered } \\
\text { from aqueous } \\
\text { ethanol extract }\end{array}$ & $\begin{array}{l}\text { Oil recovered by } \\
\text { hexane extraction of } \\
\text { pretreated kernels }\end{array}$ & $\begin{array}{c}\text { Deoiled } \\
\text { Meal }\end{array}$ \\
\hline \multirow{3}{*}{$\begin{array}{c}\text { Aqueous } \\
\text { ethanol }\end{array}$} & $95: 5$ & 3.4 & 0.6 & 0.6 & 0.9 \\
\hline & $85: 15$ & 3.6 & 0.7 & 0.6 & 0.6 \\
\hline & $75: 25$ & 3.5 & 0.6 & 0.7 & 0.7 \\
\hline+ & $50: 50$ & 3.1 & -- & 1.5 & 0.9 \\
\hline Aqueous & $30: 70$ & 3.2 & -- & 1.5 & 0.8 \\
\hline \multirow[t]{2}{*}{ Acetone } & $10: 90$ & 3.2 & -- & 1.6 & 0.7 \\
\hline & $75: 25$ & 1.4 & 1.5 & 0.8 & 1.8 \\
\hline Aqueous & $50: 50$ & 2.8 & 1.1 & 0.9 & 0.7 \\
\hline isopropanol & $40: 60$ & 3.1 & 0.8 & 1.0 & 0.6 \\
\hline
\end{tabular}

\section{RESULTS AND DISCUSSION:}

\section{Composition of experimental neem seed:}

The experimental neem seed contained $46.8 \%$ kernels and neem kernels contained $9.0 \%$ moisture, $5.5 \%$ non-lipid associates (bitters) and $43.2 \%$ oil (Table 1). The high bitter content of the kernel, if isolated could be of extensive use as anti-bacterial agent, insect repellent and for other medical purposes which have been extensively reported in the literature [11-13]. For carrying out the present study, the decorticated neem seed kernels obtained from experimental neem seeds were utilised.

Physico-chemical characteristics of crude neem oil: The analysis of the neem oil given in Table 1 indicates that free fatty acid content of the oil is high $(15.4 \%)$ which could be probably due to longer storage of neem seeds before being procured from market for extraction. The high bitter content of the oil (8.1\%) shows that about $63.2 \%$ of the total bitters of neem seed kernels were extracted along with the oil and the remaining $36.8 \%$ were left in and $12.8 \%$ linoleic acid which indicated for edible use after proper processing.

\section{Composition of deoiled neem meal:}

The deoiled meal was found to contain $33.7 \%$ proteins, $13.1 \%$ crude fibres, $12.5 \%$ moisture and $3.6 \%$ non-lipid associates (bitters) as shown in Table 1. Although the meal was rich in proteins, the high content of bitters is a limiting factor restricting its applications to only as organic manure.

Modified two-step process (single-stage pre-treatment): The first step of the process i.e. the pre-treatment of neem seeds kernels, was obviously considered as the critical step since the second step was simply the extraction of the pretreated neem seed kernels with n-hexane by conventional process. Thus, the parameters of the first step were varied systematically to study their effect on the isolation of bitters and reduction in the bitters content of the neem seed kernels before extraction of oil with n-hexane.

The temperature of pre-treatment being the most important parameter, its effect on the isolation of bitters and the reduction of bitter content of deoiled meal and oil obtained by n-hexane extraction was studied. Ethanol: water $85: 15$ $\mathrm{v} / \mathrm{v}$ ) was used as solvent at temperature ranging from $50-$ $60^{\circ} \mathrm{C}$ for $8 \mathrm{hr}$. The results depicted in Table 2 indicate that $55^{\circ} \mathrm{C}$ was the optimum temperature at which maximum amount of bitters could be extracted from neem seed kernels.

The optimum recoveries of $4.3 \%$ bitters, out of 5,5\%present in seeds (table3) by aqueous ethanol (ethanol: water, 85:15 $\mathrm{v} / \mathrm{v}$ ), 3.2\% by aqueous acetone (acetone:water,30:70) and $3.3 \%$ by isopropanol (isopropanol : water $(40: 60)$ indicated that aqueous ethanol. (ethanol: water, 85:15 v/v)has better efficiency. The bitter content of $0.6 \%$ in each of the oil obtained by $n$-hexane extraction of aqueous ethanol preheated neem kernels, and deoiled meal were also minimum compared to the corresponding values of 1.5 and $0.8 \%$, respectively by aqueous acetone (acetone:water,50:50v/v) and 1.0 and $0.6 \%$, respectively for aqueous isopropanol (isopropanol : water $(40: 60 \mathrm{v} / \mathrm{v})$.This further established the supremacy of aqueous ethanol system (ethanol: water, 85:15 v/v) over other solvents. The characteristics of oils obtained from aqueous solvents extract and from the preheated neem seed kernels shown in table 4 also indicate a superior efficacy of aqueous ethanol (ethanol : water, 85:15 v/v) system.

Although, the aqueous ethanol treatment considerably reduced the bitter content in the oil and deoiled meal, the reduction was still considered to be insufficient. To further reduce these bitter contents, the pre-treatment was carried out in three-stage counter-current manner in place of a single-stage.

Alcohol extracts contain certain value added products, e.g. non-lipid associates (bitters), colouring matter and light coloured mixed fatty acids. The oil extracted after pretreatment may be used as edible oil. Seeds with high FFA oil due to prolonged storage may also be processed for production of good quality oil. Meal with higher nutritive value, free from bitters and odoriferous materials may be produced. The active ingredient azadiractin acts as a very active insect phagorepellent and systematic growth disruptor. It is a natural herbal product which is fully biodegradable.

Table 4: Properties of active ingredient azadiractin for pesticide formulation

\begin{tabular}{|c|c|}
\hline $\begin{array}{c}\text { Active } \\
\text { ingredient: } \\
\text { Physical } \\
\text { properties: }\end{array}$ & $\begin{array}{c}\text { Azadiractin }\left(\mathrm{C}_{35} \mathrm{H}_{44} \mathrm{O}_{16}\right) \text {; Mol } \\
\text { wt: } 720 \\
\text { microcrystalline pale yellow } \\
\text { coloured crystals from } \\
\text { petroleum ether. }\end{array}$ \\
\hline $\begin{array}{l}\text { Odour: } \\
\text { Appearance: }\end{array}$ & $\begin{array}{l}\text { Neem like } \\
\text { Oily }\end{array}$ \\
\hline Colour: & Dark brown \\
\hline Specific gravity: & 1.02 at $25^{\circ} \mathrm{C}$ \\
\hline Sprayability: & Easily sprayable \\
\hline Hazards: & Non-hazardous in every way \\
\hline Viscosity & Twice than that of water. \\
\hline
\end{tabular}




\section{PESTICIDE FORMULATION}

Azadiractin, works by interrupting the reproductive cycle of insects. Once ingested, it affects the hormonal system of the insect, causing it to forget to eat and stop moulting, mating and laying eggs.This eventually sees the complete destruction of the insect population in the designated area as the older insects die off without producing offspring.Neem oil is also powerfully aromatic and gives off an odour that insects do not like, protecting plants by making them unappealing. Pesticide can be formulated in the following steps:

> A base of good-quality: $100 \%$ pure neem oil is needed which is cold pressed as head destroys the Azadirachtin. Neem oil ensures no contamination of solvents has taken place during the purification process.

$>$ Emulsification: Neem oil does not readily mix with water therefore an emulsifier like a mild liquid soap has been used.

$>$ Preparation of mixture: In order to make a litre of neem oil spray, $5 \mathrm{ml}$ of neem oil, $2 \mathrm{ml}$ of liquid soap and 1 litre of water is mixed. Soap is added to water first and then slowly neem oil is mixed with continuous stirring.

> Spray: The mixture is collected into a spray bottle which is ready to use as an effective pesticide.

\section{CONTRIBUTION TO THE SOCIETY:}

Eco-friendly literally means earth-friendly or not harmful to the environment. This term most commonly refers to products that contribute to green living or practices that help conserve resources like water etc. Eco-friendly products also prevent contributions to air, water and land pollution. For many years, we have enjoyed the benefits of using pesticides to control weed, insect, fungus, parasitic, and rodent pests. Recently, both the public and the press have increasingly focused on the negative impacts of agricultural, urban industrial, and residential chemicals. However, there are also substantial benefits to society, including:

$>$ Pesticides are the only effective means of controlling disease organisms, weeds, or insect pests in many circumstances.

$>$ Consumers receive direct benefits from pesticides through wider selections and lower prices for food and clothing.

$>$ Pesticides protect private, public, and commercial dwellings from structural damage associated with termite infestations.

$>$ Pesticides contribute to enhanced human health by preventing disease outbreaks through the control of rodent and insect populations.

$>$ Pesticides are used to disinfect indoor areas (e.g., kitchens, operating rooms, nursing homes) as well as dental and surgical instruments.

$>$ The pesticide industry also provides benefits to society.

\section{CONCLUSION:}

Pesticides contamination pose significant risks to the environment and non-target organism ranging from beneficial soil microorganism, to insects, plants, fish and birds. The best way to reduce pesticide contamination in our environment is for all of us to do our part to use safer, nonchemical pest control methods. With the knowledge of synthetic pesticides, worldwide attention is rapidly shifting to non-synthetic, safe pesticides. Neem extract - pesticide formulation is a water based formulation of a biological material which mainly contain an active ingredient Azadiractin which acts as a very active insect phagorepellent and systematic growth disruptor. It is a natural herbal product which is fully bio-degradable. Pesticides are often considered a quick, easy and inexpensive solution for controlling weed and insect pest in urban landscapes. It has contaminated almost every part of our environment and residues are found in soil, air, surface and ground water.

\section{REFERENCES:}

[1] Puri, H,S.Neem-The Divine Tree Harwood Academic Publisher, Amsterdam (1999).

[2] Ragasa,C.Y., Nacpil,Z.D., Natividad,G.M., Tada,M., Coll.J.C. and Rideout,J.A, Tetranortriterpenoids from Azadirachta Indica., Journal of Phytochemistry,46,555 (1997).

[3] Warden, C.D., Forest Resources of the Baroda State, Baroda Printing Works, Baroda, Bull.2, $2^{\text {nd }}$ Ed., 10 (1921).

[4] https://www.sciencedirect.com/science/article/pii/S1 872203218301641 (2018)

[5] Godrej, N.B., J. Oil Tech. Assocn. Of India, 14, 39 (1982).

[6] Kane, J.G., Rao, V.R. and Subrahmanyam V.V.R., J. Oil Technol. Assocn. Of India, 5, 59, (1973).

[7] Mitra, C.R., Indian Oilseeds J., 1, 256 (1957).

[8] Siddiqui, S. and Mitra, C.R., Indian Patents, 33, 649 (1946), 33, 650 (1946), 33, 651 (1946).

[9] Sinha, N.P. and Gulati, K.C., Abstr., Second Indian Oilseeds Res. Workers Conference, Indian Central Oilseeds Committee (1961).

[10] Official and Tentative methods, American Oil Chemists' Society, Champaign, Illinois, (1973).

[11] Chatterjee, A.K. and Roy, C., Ind. J. of med. Res., 5, 656 (1917).

[12] Sinha, K.C., Riar, S.S. and Vardhan J., Indian J. Med. Res., 131 (1984).

[13] http://npic.orst.edu/ingred/ptype/natbio.html (2018) 